\title{
CERVICAL PESSARY PLUS VAGINAL PROGESTERONE IN A SINGLETON PREGNANCY WITH A SHORT CERVIX: AN ANALYSIS OF EFFICACY BASED ON THE LEARNING CURVE AND CUMULATIVE SUM ANALYSIS (LC-CUSUM) IN A QUASI-RANDOMIZED CLINICAL TRIAL
}

\author{
Marcelo Franca ${ }^{1}$, Alan Hatanaka ${ }^{1}$, Jader Cruz ${ }^{2}$, Valter Andrade Jr. ${ }^{3}$, Tatiana Hamamoto ${ }^{1}$, \\ Stephanno Sarmento ${ }^{4}$, Julio Elito Jr. ${ }^{1}$, David Pares ${ }^{1}$, Rosiane Mattar ${ }^{1}$, and Antonio \\ Moron $^{1}$ \\ ${ }^{1}$ Federal University of Sao Paulo \\ ${ }^{2}$ Centro Hospitalar de Lisboa Central EPE \\ ${ }^{3}$ Impacta Certification Training \\ ${ }^{4}$ Faculdade de Medicina de Jundiai
}

September 11, 2020

\begin{abstract}
Objective This study aims to determine the performance of cervical pessary in singleton pregnancies with a short cervix based on the learning curve. Design, Settings, Population, and Methods Between 2011 and 2018, 128 singleton gestation between 18 th to 24 th weeks with a short cervix $(<25 \mathrm{~mm})$ were referred to our quasi-randomized trial. All cases were treated with progesterone, and, when available, cervical pessary was also offered. Three groups were created for statistical analysis: Group 1 ( $\mathrm{n}=33$ ), treated with progesterone-only; Group 2 and Group 3, treated with cervical pessary plus progesterone. Group 2, included the first cases $(n=30)$, defined by the learning curve and cumulative sum analysis (LC-CUSUM), while Group 3, included the subsequent $(\mathrm{n}=65)$. Our outcome was delivery before 34 weeks. Main outcome measures and Results LC-CUSUM demonstrated that 30 patients achieved learning. The preterm birth rate before 34 weeks was $27.3 \%$ in Group 1, 20\% in Group 2 , and $4.6 \%$ in Group 3. There was no significant difference in the Group 1/Group 2 comparison (OR 1.10, P=0.945); the Group 1/Group 3 comparison, the difference was significant (OR 0.08, $\mathrm{P}=0.003$ ). Conclusion LC-CUSUM determined 30 pessaries to achieve the best pessary performance. Cervical pessary plus progesterone can reduce the preterm birth before 34 weeks in patients with a short cervix. Funding This study was financed in part by the Coordenação de Aperfeiçoamento de Pessoal de Nível Superior Brazil (CAPES) - Finance Code 001 Keywords Preterm birth; learning curve; cervical pessary; vaginal progesterone; singleton pregnancy; short cervix; transvaginal ultrasound.
\end{abstract}

\section{Hosted file}

Main article BJOG.docx available at https://authorea.com/users/331691/articles/480593cervical-pessary-plus-vaginal-progesterone-in-a-singleton-pregnancy-with-a-short-cervixan-analysis-of-efficacy-based-on-the-learning-curve-and-cumulative-sum-analysis-lccusum-in-a-quasi-randomized-clinical-trial

\section{Hosted file}

Figure 1.docx available at https://authorea.com/users/331691/articles/480593-cervical- 
pessary-plus-vaginal-progesterone-in-a-singleton-pregnancy-with-a-short-cervix-ananalysis-of-efficacy-based-on-the-learning-curve-and-cumulative-sum-analysis-lc-cusumin-a-quasi-randomized-clinical-trial

\section{Hosted file}

Table 1.docx available at https://authorea.com/users/331691/articles/480593-cervical-pessaryplus-vaginal-progesterone-in-a-singleton-pregnancy-with-a-short-cervix-an-analysis-ofefficacy-based-on-the-learning-curve-and-cumulative-sum-analysis-lc-cusum-in-a-quasirandomized-clinical-trial

\section{Hosted file}

Figure 2.docx available at https://authorea.com/users/331691/articles/480593-cervicalpessary-plus-vaginal-progesterone-in-a-singleton-pregnancy-with-a-short-cervix-ananalysis-of-efficacy-based-on-the-learning-curve-and-cumulative-sum-analysis-lc-cusumin-a-quasi-randomized-clinical-trial

\section{Hosted file}

Table 2.docx available at https://authorea.com/users/331691/articles/480593-cervical-pessaryplus-vaginal-progesterone-in-a-singleton-pregnancy-with-a-short-cervix-an-analysis-ofefficacy-based-on-the-learning-curve-and-cumulative-sum-analysis-lc-cusum-in-a-quasirandomized-clinical-trial 